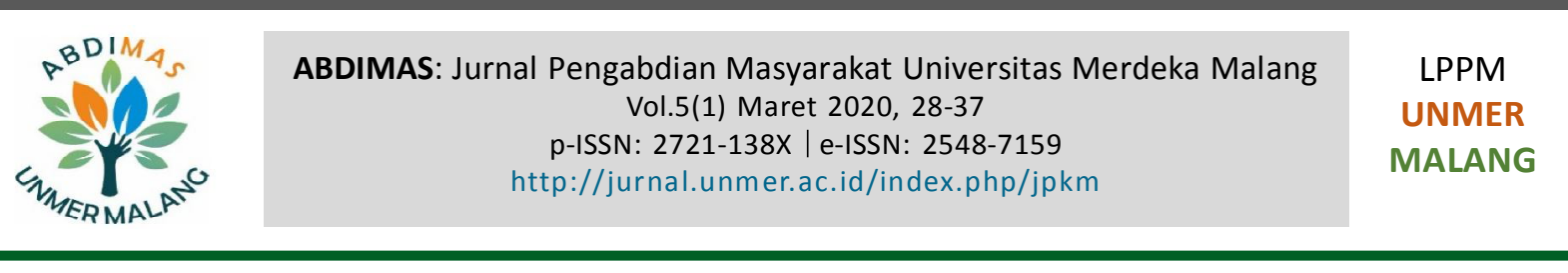

\title{
Peningkatan Pembelajaran Student-Centered SMAK Santo Yusup Surabaya melalui Penataan Ruang Kelas
}

\author{
Lya Dewi Anggraini ${ }^{1}$, Natalia Christiani ${ }^{2}$, Hebert Adrianto ${ }^{3}$ \\ ${ }^{1}$ Departemen Arsitektur Interior, Fakultas Industri Kreatif, ${ }^{2}$ Departemen Manajemen, Fakultas Ekonomi dan Bisnis, \\ ${ }^{3}$ Departemen Kedokteran, Fakultas Kedokteran Universitas Ciputra, Surabaya \\ CitraLand CBD Boulevard, Surabaya, 60219, Indonesia
}

\section{ARTICLE INFO:}

Received: 2019-05-31 Revised: 2019-09-04 Accepted: 2020-01-06

Keywords

Classroom

atmosphere;

Communication media;

Learning methods

\begin{abstract}
One important factor in improving the quality of learning is the classroom atmosphere, which is formed through the activities carried out in it between the teacher and students with position, posture, and body language, as non-verbal communication, and the use of words, intonation, and pronunciation as verbal communication. Another important factor is the characteristics of the space where the activity takes place (setting). In applying the student-centered approach, which motivates students to learn more actively and not depend on the teacher, the role of a teacher is very important to always be able to improvise, exploit the potential and position, for the success of the teaching-learning process in schools. The purpose of activities in the field of interior science architecture community service at SMAK St. This framework is to strengthen the participation of teachers and students through the setting of learning spaces that support the establishment of communication as desired. The method used is observation of the physical environment and surveys of teachers and students about the communication experience and the convenience of learning on three subjects that are considered difficult, namely Chemistry, Biology, and English. The survey results show that effective verbal and non-verbal communication media between teachers and students and fellow students is triggered by the setting of the space outside the classroom, with more relaxed and enjoyable reasons, such as in a library room. This has a real impact on increasing student motivation in the form of subjects' likes and grades. Other results indicate an increase in teacher awareness that changes in varied learning space settings can support non-verbal communication with students.
\end{abstract}

(c) 2020 Published by University of Merdeka Malang This is an open access article distributed under the CC BY-SA 4.0 license (https://creativecommons.org/licenses/by-sa/4.0/)

How to cite: Anggraeni, Lya Dewi. (2020). Peningkatan Pembelajaran Student-Centered SMAK Santo Yusup Surabaya melalui Penataan Ruang Kelas. Abdimas: Jurnal Pengabdian Masyarakat Universitas Merdeka Malang, 5(1), 28-37. https://doi.org/10.26905/abdimas.v5i1.3100

\section{PENDAHULUAN}

Sekolah Menengah Atas Katolik Santo Yusup (SMAK St. Yusup) Kelurahan Kebraon Kecamatan Karangpilang Kota Surabaya Provinsi Jawa Timur yang berlokasi di Jl. Kebraon Gang I Barat Karangpilang No.6, sebuah sekolah swasta di bawah naungan Yayasan Yohanes Gabriel, menjadi salah satu mitra 


\section{Peningkatan Pembelajaran Student-Centered SMAK Santo Yusup Surabaya...}

Lya Dewi Anggraini, Natalia Christiani, Hebert Adrianto

Universitas Ciputra dalam kegiatan pengabdian kepada masyarakat. Permasalahan SMAK St. Yusup secara umum adalah menurunnya motivasi belajar siswa pada beberapa mata pelajaran dan kesulitan guru berkomunikasi dan menjaga suasana kelas. Permasalahan secara khusus adalah rendahnya kesadaran guru terhadap pentingnya penataan ruang kelas untuk mendukung komunikasi yang efektif. Di sisi lain, banyak riset yang menunjukkan bahwa penataan ruangan kelas ataupun kantor memengaruhi produktivitas kerja (Haynes, 2008; Arimbawa \& Santhyasa, 2010; Feige et al., 2013; Yunus \& Ernawati, 2018). Program pengabdian masyarakat ini dirancang untuk mendesain ulang ruangan kelas agar tercipta kondisi lingkungan kerja yang lebih kondusif dan nyaman sehingga dapat meningkatkan kinerja siswa, guru, dan staf di sekolah.

Selama proses identifikasi permasalahan, ditemukan adanya keunikan dan kekhususan yang melibatkan keterkaitan antara sumber daya manusia dan sumber daya lingkungan yang ada di sekolah tersebut, sehingga penyelesaian terbaik akan ditindaklanjuti melalui metode partisipasi aktif guru dan murid dalam dua hal: (1) peningkatan kesadaran potensi diri dan (2) penerapan pengetahuan secara praktis. Partisipasi guru dan murid menjadi modal utama dalam rangka meningkatkan kualitas sekolah sebagai tempat belajar yang layak dan kondusif bagi siswa, karena merekalah pengguna sekaligus pelaku utama yang melakukan perubahan dalam lingkungan sekolah yang potensinya dapat diarahkan untuk menyelesaikan permasalahan.

Sebagai tempat berkembangnya dan disebarkannya pengetahuan, SMAK St. Yusup layak mendapatkan perhatian besar, terlepas dari kemampuan pihak sekolah, karena pengetahuan punya kekuatan untuk mengubah. Secara umum, terdapat empat hal yang dapat dieksplorasi dari sekolah (Ford, 2007), yaitu akustik yang bagus, bebas dari kebisingan dan getaran yang berlebihan ketika guru dan murid dapat saling berbicara dan mendengarkan dengan baik sebagai mode komunikasi utama dalam setting pendidikan. Masalahnya sering kali sekolah berada di lokasi yang kurang tepat, atau lingkungan yang terlalu bising dan banyak pengalih perhatian. Hal kedua adalah kenyamanan visual, yaitu ketajaman dan persepsi kedalaman yang baik, yang dapat dipenuhi dari jarak pandang yang memadai (Idham, 2016), yang sangat mempengaruhi proses pembelajaran. Anak dengan keterbatasan, memusatkan perhatian memiliki karakteristik yang khas dalam memilih informasi yang mempengaruhinya dari terlalu banyak informasi yang bisa mengganggu. Hal ketiga adalah pencahayaan terkait kesulitan dalam memperhatikan secara sekilas, di sekolah dengan lingkungan pencahayaan yang tepat, tingkat perhatian dan kecakapan siswa akan meningkat, seiring dengan meningkatnya informasi lebih efektif (Ford, 2007). Pencahayaan tidak langsung juga dideteksi memiliki pengaruh terhadap informasi yang disampaikan. Hal keempat adalah persepsi terhadap warna, yang dikaitkan dengan emosi, faktor yang dipengaruhi oleh usia, mood, dan kesehatan mental (Laurens, 2004). Anak dengan kepribadian yang berbeda-beda akan saling berbagi kesukaan terhadap warna, seperti anak kecil yang menyukai warna tertentu yang dapat menjadi semacam terapi terhadap ketidakmampuan fisik dan mental (Ford, 2007).

Capaian pembelajaran siswa yang disusun dalam bentuk panduan, untuk membantu mengarahkan pendidik dalam melaksanakan tugasnya, dalam penerapannya, tidak serta-merta berhasil. Ada faktor manusia yang harus diperhitungkan, serta faktor lingkungan yang turut membentuk dan mempengaruhi suasana pembelajaran (Haynes, 2008; Hameed \& Amjad, 2009; Boys, 2011). Di SMAK St. Yusup, kedua faktor tersebut akan diidentifikasi dan dikaitkan satu sama lain sehingga tercapai penyelesaian yang terbaik. Komunikasi dipengaruhi oleh keberimbangan jumlah guru dan siswa (1:11) serta guru dan mata pelajaran (1:2) atau guru dan kelas (1:2) yang dapat berpotensi sebagai permasalahan. Tabel berikut adalah gambaran perbandingan jumlah guru dan siswa terhadap mata pelajaran. 
ABDIMAS: Jurnal Pengabdian Masyarakat Universitas Merdeka Malang

Volume 5, No 1, Maret 2020: 28-37

Tabel 1. Perbandingan jumlah siswa, guru, dan mata pelajaran*

\begin{tabular}{lccc}
\hline & Jumlah Siswa & Jumlah Guru (Mata Pelajaran) \\
\hline IPA & & Kelas X & \\
IPS 1 & 30 & & $14(17)$ \\
IPS 2 & 31 & & \\
\hline \multicolumn{4}{l}{} \\
\hline IPA & 35 & Kelas XI & $13(16)$ \\
IPS 1 & 34 & & \\
IPS 2 & 28 & & \\
\hline
\end{tabular}

* Total kelas X dan XI berjumlah 186 siswa dan 17 guru yang mengajar enam kelas tersebut untuk semua mata pelajaran kecuali Matematika dan Inggris.

Berdasarkan hasil wawancara dan pengamatan awal, beberapa permasalahan yang ditemukan di SMAK St. Yusup akan berpusat pada tiga mata pelajaran: Biologi, Bahasa Inggris, dan Kimia, yang dianggap memiliki potensi penyelesaian yang baik.

Tabel 2. Permasalahan dan Penyelesaian

\begin{tabular}{cll}
\hline Mata Pelajaran & \multicolumn{1}{c}{ Permasalahan } & \multicolumn{1}{c}{ Penyelesaian } \\
\hline Biologi & $\begin{array}{l}\text { Terbatasnya pengetahuan guru terhadap } \\
\text { materi karena banyak, abstrak, sulit } \\
\text { dipahami siswa }\end{array}$ & $\begin{array}{l}\text { Meningkatkan pengetahuan guru tentang materi dan } \\
\text { keterampilan dalam mengajar }\end{array}$ \\
Bahasa Inggris & $\begin{array}{l}\text { Guru memiliki kemampuan terbatas dalam } \\
\text { metode pengajaran siswa zaman now }\end{array}$ & $\begin{array}{l}\text { Mengenalkan strategi pembelajaran yang berfokus } \\
\text { pada student-centered learning yang sesuai karakter } \\
\text { menarik dan inovatif seperti games }\end{array}$ \\
& $\begin{array}{l}\text { Guru memiliki keterbatasan dalam } \\
\text { mengelola ruang kelas dan laboratorium } \\
\text { sehingga menurunkan minat siswa }\end{array}$ & $\begin{array}{l}\text { Mengubah suasana belajar dengan memanfaatkan } \\
\text { ruang dan mengelola benda-benda yang ada sebagai } \\
\text { media komunikasi yang efektif }\end{array}$ \\
\hline
\end{tabular}

\section{METODE}

Terdapat dua faktor penting dalam angket: peran guru dan kondisi fisik kelas yang dapat memengaruhi kenyamanan dan timbulnya minat belajar siswa dalam mengikuti pembelajaran di kelas. Isian angket guru dan angket siswa yang berisi dua bagian pertanyaan (1) Angket semua guru yang bersedia yang lebih fokus ke suasana kelas dengan dua kelas yang mengisi angket siswa, yaitu kelas X dan XI dalam satu angket yang sama, dibagi oleh waktu. (2) Angket siswa lebih fokus ke suasana kelas yang diajar oleh guru dalam tiga kelas yang berbeda dalam satu angket yang sama dengan pembagian waktu bertahap.
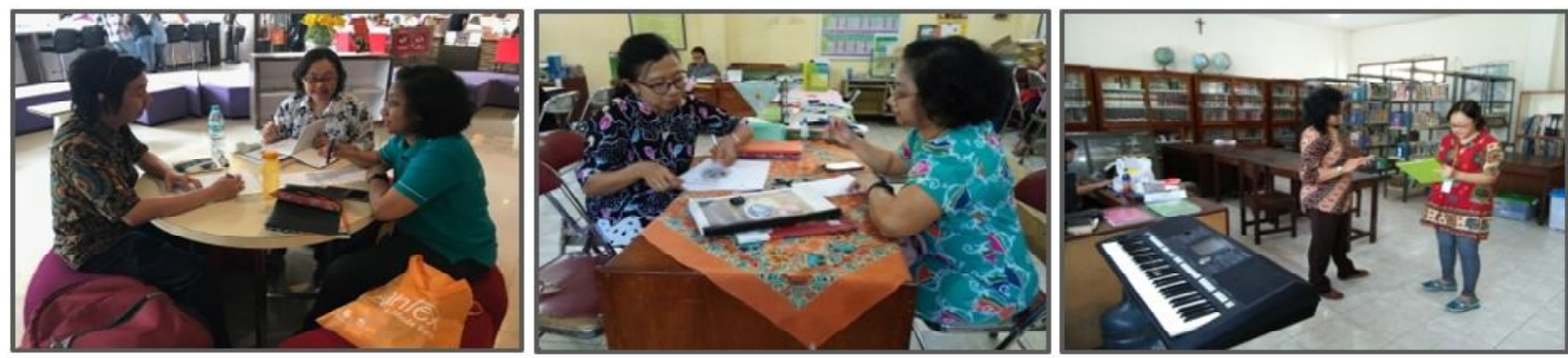

Gambar 1. Diskusi, wawancara tahap pertama 


\section{Peningkatan Pembelajaran Student-Centered SMAK Santo Yusup Surabaya...}

Lya Dewi Anggraini, Natalia Christiani, Hebert Adrianto
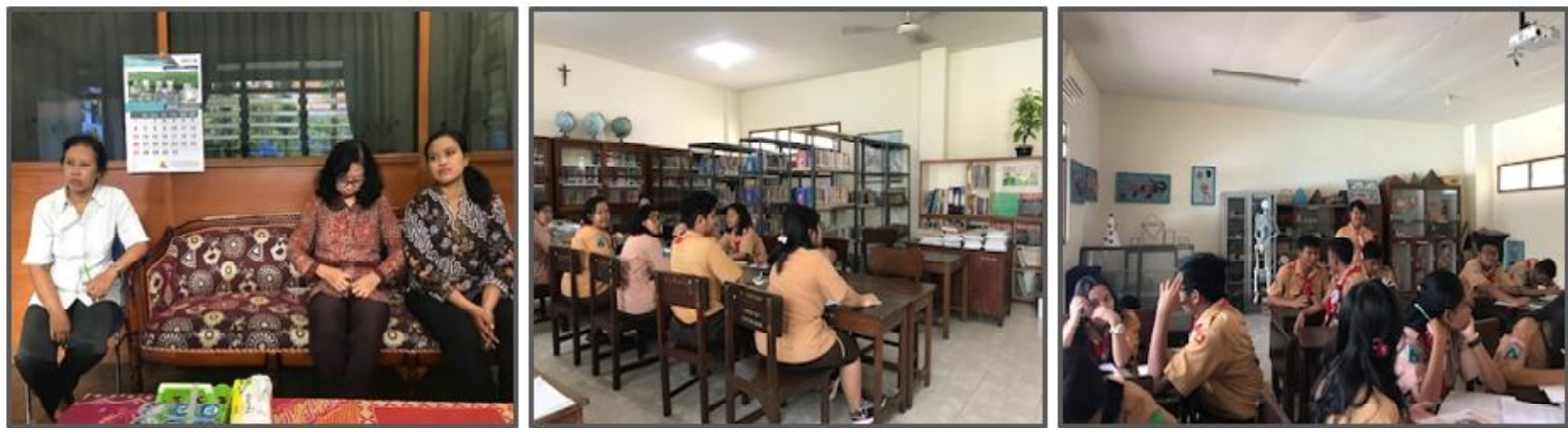

Gambar 2. Survei selama kunjungan tahap pertama terhadap guru dan siswa

Pengamatan lapangan dan pendataan kondisi fisik ruang-ruang pembelajaran dilaksanakan secara bertahap dalam tiga kali kunjungan selama 2 jam dan disandingkan dengan standar pemerintah atau standar nasional yang berlaku. Dengan menyasar pada tiga mata pelajaran yang dianggap paling krusial, yaitu Kimia (K), Biologi (B), dan Inggris (I), terutama terhadap siswa kelas X dan XI, kegiatan ini diharapkan akan membantu meningkatkan kepekaan guru terhadap peran lingkungan fisik dan non-fisik dalam membangkitkan suasana kelas student-centered yang komunikatif.

Pertanyaan angket untuk siswa terbagi dalam dua potensi, yaitu: (1) komunikasi (2) suasana kelas seperti diuraikan pada Tabel 3.

Tabel 3. Isi angket survei untuk siswa

\begin{tabular}{|c|c|c|}
\hline Potensi & Sub-potensi & Penjelasan \\
\hline \multirow{5}{*}{ Komuni-kasi } & Internet & $\begin{array}{l}\text { Aplikasi yang paling sering digunakan siswa terkait } \\
\text { materi/tugas }\end{array}$ \\
\hline & Media & $\begin{array}{l}\text { Media yang palign sering digunakan guru } \\
\text { menyampaikan materi/tugas }\end{array}$ \\
\hline & & - Komunikasi antara siswa dan guru \\
\hline & Personal & $\begin{array}{l}\text { - Tingkat pemahaman siswa terhadap penjelasan guru } \\
\text { - Keakraban dengan teman sekelas }\end{array}$ \\
\hline & Konsentrasi & $\begin{array}{l}\text { Kemudahan siswa berkonsentrasi terhadap gangguan } \\
\text { komunikasi }\end{array}$ \\
\hline \multirow{10}{*}{ Suasana kelas } & Pencahayaan buatan & Tingkat terang lampu dalam kelas \\
\hline & Pencahayaan alami & Tingkat terang cahaya matahari \\
\hline & Produktivitas & Tingkat penyelesaian tugas-tugas \\
\hline & Pengaturan waktu & $\begin{array}{l}\text { Lamanya jam belajar disesuaikan dengan kebutuhan } \\
\text { memahami tugas }\end{array}$ \\
\hline & Kondisi suhu & Tingkat kenyamanan termal \\
\hline & Kesesakan & Jumlah siswa terhadap ukuran ruang \\
\hline & Kebisingan & Kenyamanan auditorial siswa \\
\hline & Ukuran ruang & Luas atau sempit menurut siswa \\
\hline & Suasana hati & Menyenangkan atau membosankan \\
\hline & Kenyamanan duduk & Posisi duduk siswa saat mendengarkan di kelas \\
\hline
\end{tabular}


ABDIMAS: Jurnal Pengabdian Masyarakat Universitas Merdeka Malang Volume 5, No 1, Maret 2020: 28-37

Tabel 4. Isi angket survei untuk guru

\begin{tabular}{lll}
\hline Potensi & Sub-potensi & Tingkat kenyamanan \\
\hline Komunikasi personal & Privasi & - Saat suara terdengar atau didengar \\
& & - Saat melihat atau dilihat \\
& Konsentrasi & - Saat mendekat atau didekati \\
& Komunikasi & - Selama bekerja dalam ruangan \\
& - Selama memberikan penjelasan \\
& Konsistensi & - Dengan sesama guru \\
\hline Suasana kelas & Perabotan & - Dengan siswa \\
& & - Mntukengingat detil pekerjaan \\
& Pengaturan peja dan kursi \\
& - Ketinggian meja dan kursi \\
& - Ukuran meja dan kursi \\
& - Letak meja dan kursi \\
& & - Letak papan tulis atau layar LCD \\
\hline
\end{tabular}

\section{HASIL DAN PEMBAHASAN}

\section{Hasil}

Tahap pertama kegiatan pengabdian yang dapat dilaksanakan dalam kurun waktu kunjungan yang cukup singkat, telah mampu mengumpulkan sebanyak 50 anak, dengan tingkat respons $100 \%$. Jumlah guru yang berhasil diwawancara adalah 5 orang, yaitu guru Biologi, guru Kimia, dua orang guru Bahasa Inggris, Wakil Kepala Sekolah yang merangkap guru Kimia, dan Kepala Sekolah.

Hasil perbandingan tiga mata pelajaran, Kimia, Biologi, dan Bahasa Inggris, menunjukkan bahwa dari antara siswa yang menyukai mata pelajaran tertentu, juga memperoleh nilai tinggi di pelajaran tersebut, yaitu Kimia. Sebaliknya, siswa yang tidak menyukai mata pelajaran, yaitu Bahasa Inggris, juga memperoleh nilai terendah. Sementara, menurut siswa, mata pelajaran Biologi tidak menunjukkan kesan maupun performa yang menyolok (Gambar 3).

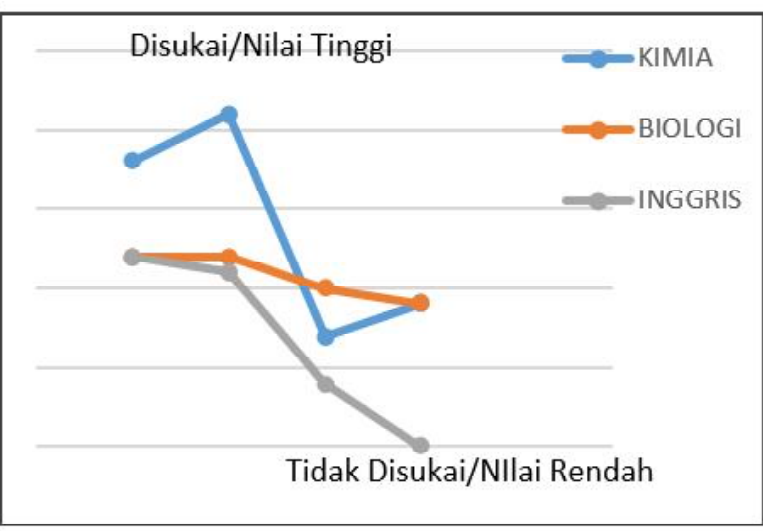

Gambar 3. Mata pelajaran yang disukai/tidak disukai terhadap nilai

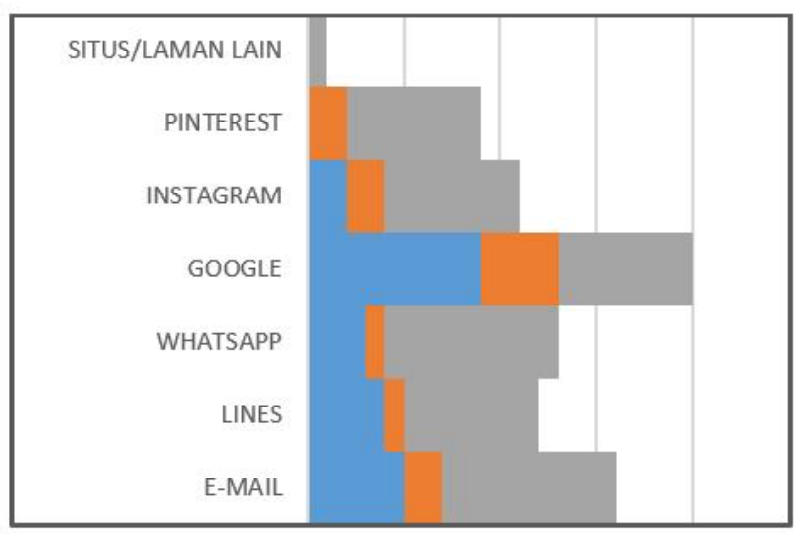

Gambar 4. Penggunaan media daring dan komunikasi tatap muka 


\section{Peningkatan Pembelajaran Student-Centered SMAK Santo Yusup Surabaya...}

Lya Dewi Anggraini, Natalia Christiani, Hebert Adrianto

Metode pembelajaran yang digunakan oleh masing-masing guru, sangat bervariasi, dan telah memanfaatkan teknologi. Mulai dari media sosial daring, yaitu e-mail, LINE, Whatsapp, mesin pencari Google, Instagram, dan Pinterest. Beragam metode dapat dilakukan untuk meningkatkan kinerja guru dalam pelaksanaan proses belajar mengajar. Salah satu bentuk peningkatan kinerja guru yang dilakukan dalam pengabdian ini adalah pemanfaatan laboratorium dan jaringan komputer untuk mengoptimalkan metode evaluasi terhadap peserta didiknya (Yudhistiro, 2019). Dalam penyampaian materi di kelas juga bervariasi antara menggunakan layar LCD dengan powerpoint, cetak/fotokopi, diskusi/tanya jawab, ceramah, hingga papan tulis. Variasi metode pembelajaran yang tinggi tersebut jika dikaitkan dengan mata pelajaran yang paling tidak disukai (Bahasa Inggris), mengindikasikan bahwa kekerapan penggunaan teknologi komunikasi atau media sosial daring seperti yang dilakukan di kelas Bahasa Inggris tidak menjamin pelajaran lebih disukai dan performa siswa bagus. Sebaliknya, meskipun metode pembelajaran diskusi/tanya jawab dan papan tulis lebih sering dilakukan di kelas Kimia, dengan penggunaan media daring lebih terbatas, terbukti pelajaran menjadi lebih disukai sehingga performa siswa tinggi (Gambar 4).

Suasana kelas yang dapat dikendalikan sepenuhnya oleh guru ternyata sangat memengaruhi keberhasilan pembelajaran, yang diukur dari rasa suka, keakraban dengan guru dan sesama siswa, suasana hati yang senang, kenyamanan, dan hal positif lain (Rapoport, 2005; Hameed \& Amjad, 2009; Yusup, 2016). Suasana kelas dengan pelajaran dan guru yang berbeda dapat mempengaruhi perbedaan persepsi siswa terhadap kondisi dan situasi ruang, meski secara fisik sama. Berdasarkan hasil survei, terindikasi sikap positif dalam proses pembelajaran, yaitu mudah memahami penjelasan dan produktivitas tinggi pada pelajaran Kimia (Gambar 5). Kondisi dan situasi yang biasa saja setara dengan sikap dan motivasi siswa terhadap mata pelajaran Biologi yang biasa saja (Gambar 6).

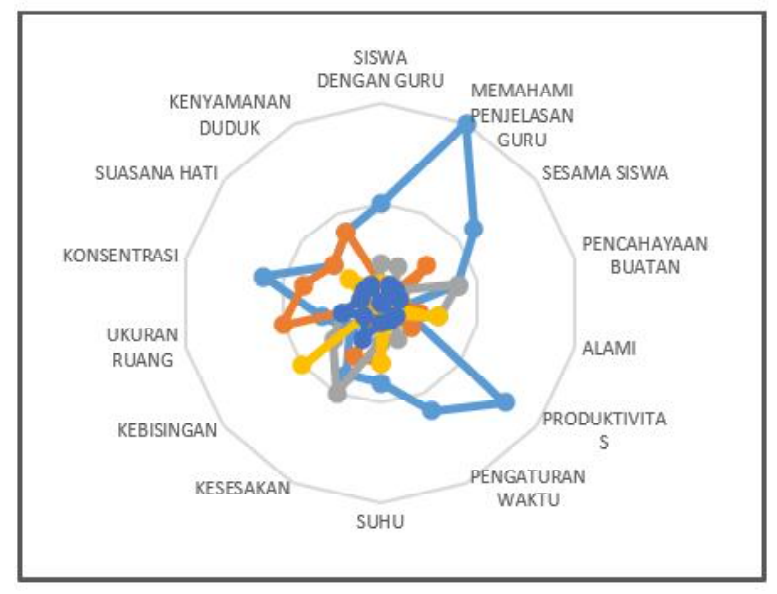

Gambar 5. Persepsi siswa terhadap suasana kelas Kimia

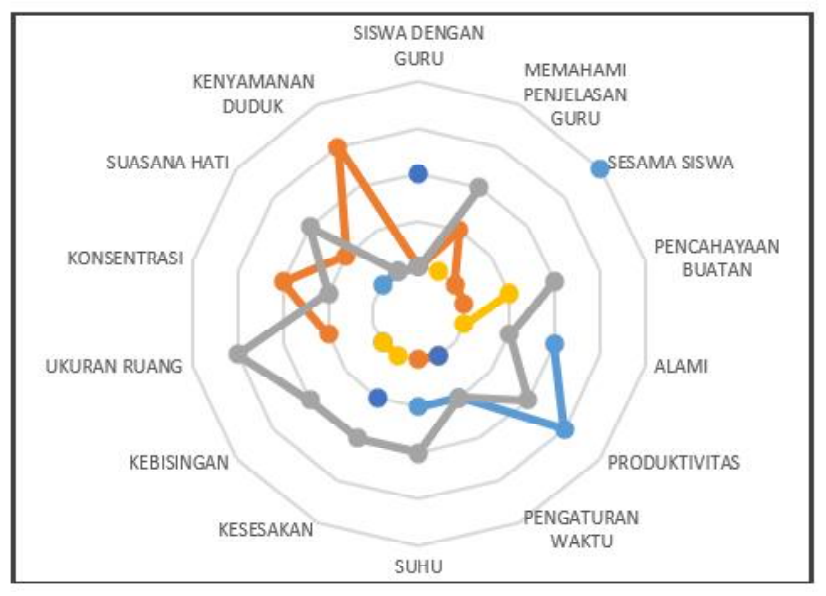

Gambar 6. Persepsi siswa terhadap suasana kelas Biologi

Demikian pula sebaliknya, suasana kelas dipersepsikan negatif di kelas Bahasa Inggris yang kurang/ tidak disukai (Gambar 7).

Faktor lain pendukung suasana kelas adalah adanya pergantian suasana, misalnya dengan melaksanakan kegiatan diskusi mata pelajaran Kimia dalam ruang perpustakaan, yang dilakukan sekali 
ABDIMAS: Jurnal Pengabdian Masyarakat Universitas Merdeka Malang Volume 5, No 1, Maret 2020: 28-37

dalam sebulan, yang mengajak siswa menggali sendiri informasi melalui buku, kemudian dipresentasikan dan didiskusikan dengan siswa lain.

Suasana yang santai terbentuk karena siswa memilih duduk di lantai undakan berkarpet, dengan posisi yang lebih bebas, meskipun tersedia kursi dan meja. Selama siswa presentasi dan berdiskusi, guru hanya memberi instruksi dan memperbaiki kesalahan atau pertanyaan yang tidak dapat dijawab oleh siswa.

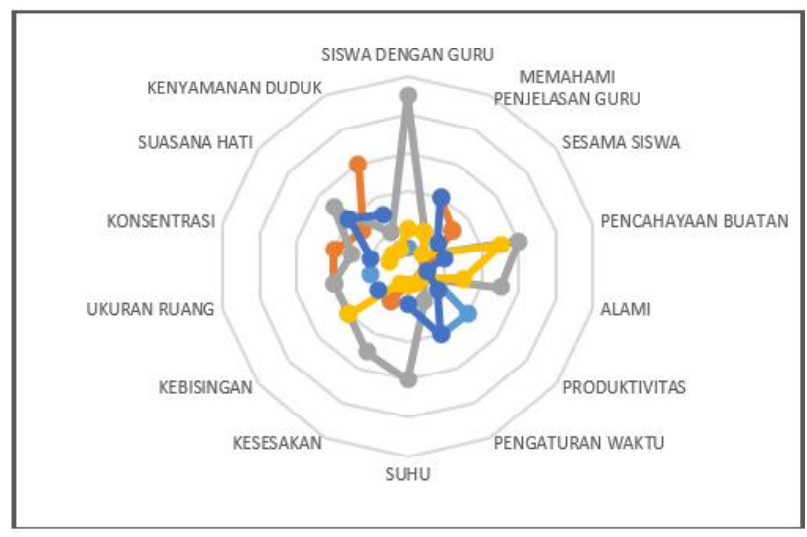

Gambar 7. Persepsi siswa terhadap suasana kelas Bahasa Inggris

Perubahan ruang secara fisik yang berdampak terhadap perubahan suasana yang lebih kondusif, telah diinisiasi oleh Wakil Kepala Sekolah, setelah kunjungan pertama dilakukan. Hasilnya telah diakui lebih positif dalam meningkatkan suasana kerja dan suasana pembelajaran yang lebih kondusif.
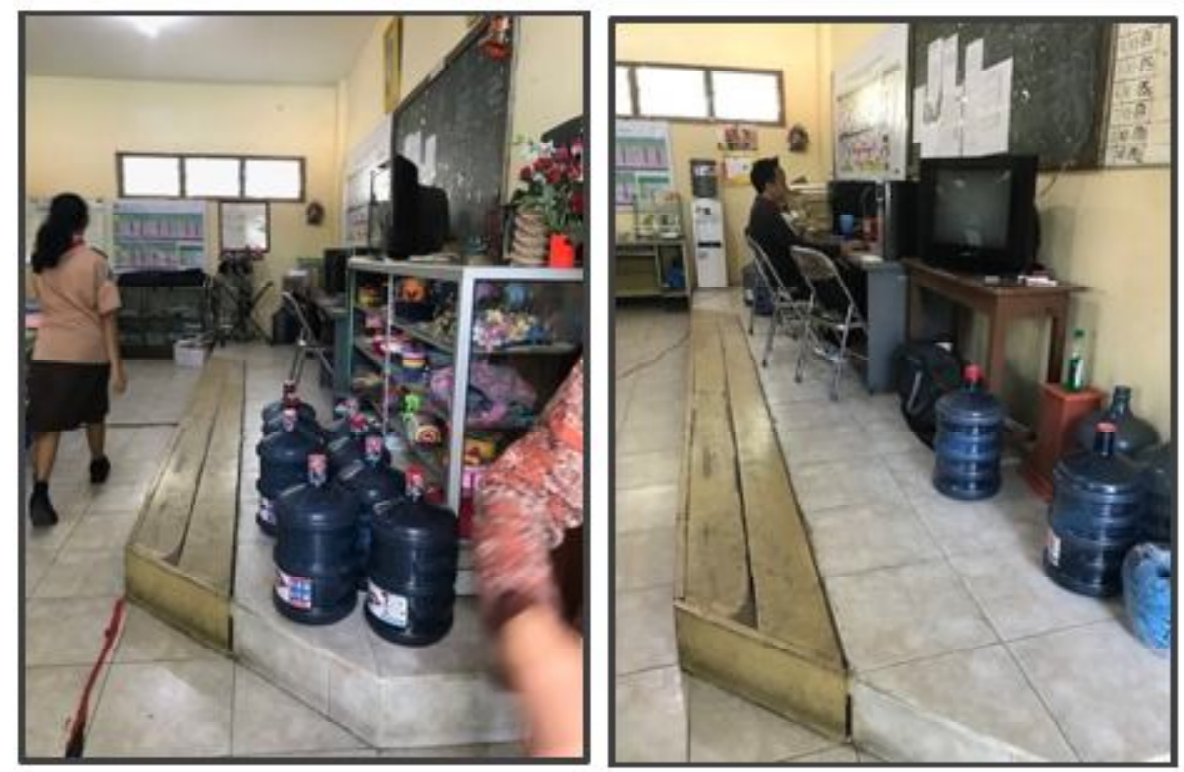

Gambar 8. Penambahan fasilitas dalam ruang guru untuk siswa 


\section{Peningkatan Pembelajaran Student-Centered SMAK Santo Yusup Surabaya...}

Lya Dewi Anggraini, Natalia Christiani, Hebert Adrianto
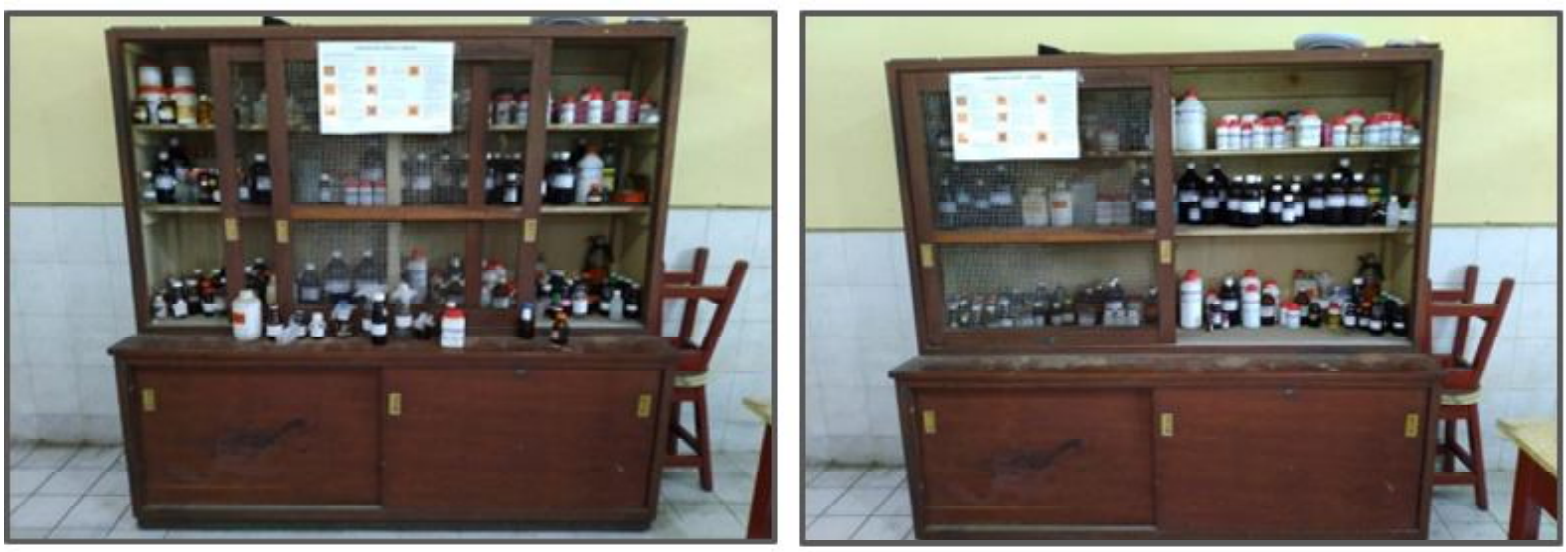

Gambar 9. Penataan dan pelabelan bahan kimia

Perubahan tersebut terjadi pada ruang guru melalui penambahan fasilitas pencari informasi daring untuk siswa (gambar 8; kiri sebelum, kanan sesudah), pada ruang laboratorium Kimia melalui penataan dan pelabelan bahan kimia (gambar 9; kiri sebelum, kanan sesudah), dan perubahan suasana ruang guru dengan memindahkan dan merapikan sebagian karya siswa yang disimpan dan dipajang dengan apik (Gambar 10; kiri sebelum, kanan sesudah).
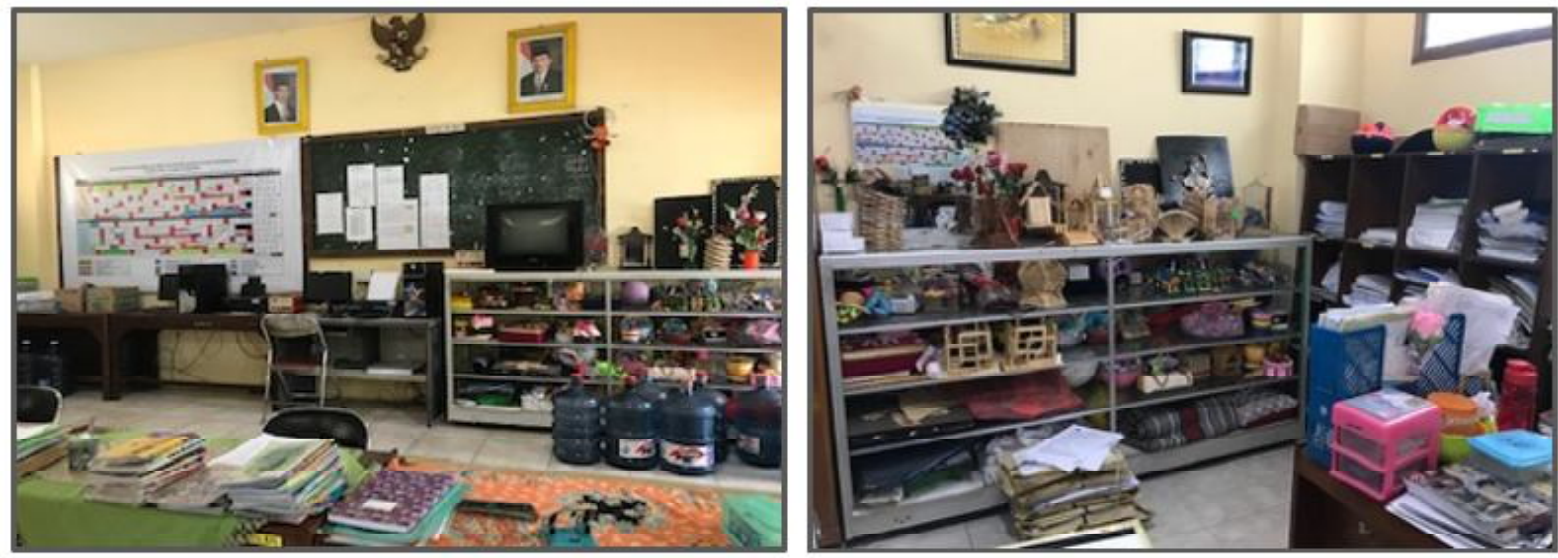

Gambar 10. Perubahan suasana ruang guru

Sebagai tambahan, dari hasil wawancara mendalam dan ekstensif terhadap lima orang guru selama kunjungan ini, beberapa hal penting dapat dirangkum antara lain: (1) Persepsi siswa terhadap waktu (lamanya pembelajaran) dipengaruhi saat guru sanggup mengendalikan kelas, siswa akan patuh dan menurut, sehingga waktu yang dibutuhkan untuk menyampaikan materi pelajaran kepada siswa akan lebih singkat (efektif). (2) Terbangunnya suasana kelas sangat dipengaruhi oleh kemampuan guru menjaga konsentrasi siswa, dengan mengendalikan ketenangan, sehingga kebisingan bisa ditekan dan siswa lebih dapat memusatkan perhatian kepada guru. (3) Kemampuan siswa memahami materi atau tugas, saat diberi waktu untuk bekerja sendiri, di dalam maupun luar ruangan kelas, dipengaruhi kebebasan dalam cara melakukannya, (seperti menggunakan ruangan perpustakaan pada saat pelajaran kimia) mencari referensi atau buku sendiri 
ABDIMAS: Jurnal Pengabdian Masyarakat Universitas Merdeka Malang

Volume 5, No 1, Maret 2020: 28-37

(dalam ruang perpustakaan), dan tidak harus duduk di kursi kelas, namun bisa duduk di lantai, sehingga lebih santai, dengan posisi dan lokasi yang bebas. Ruangan yang dibiarkan terbuka (ruang perpustakaan terletak paling pojok) tidak mengganggu meskipun terang sinar matahari atau suara dari luar turut masuk.

\section{SIMPULAN DAN SARAN}

\section{Simpulan}

Secara prinsip, pembelajaran di kelas yang disukai oleh siswa sangat terkait dengan suasana kelas yang dibentuk dari cara mengajar dan mengendalikan kelas, serta pergantian suasana kelas misalnya dengan memindahkan ruang kegiatan di luar ruang kelas yang biasa dipakai (Ngalimun, 2017). Namun demikian, peran guru tetaplah lebih besar daripada kondisi fisik ruang kelas karena guru bisa mengubah kondisi fisik ruang yang terbatas menjadi lebih nyaman melalui kendali yang menjadi otoritasnya (Habraken, 2000). Secara umum, penjelasan hasil angket dan wawancara siswa dan guru dapat disimpulkan (1) Pelajaran yang disukai, cenderung mendorong siswa untuk lebih menunjukkan produktivitasnya melalui tugas dan ujian sehingga nilai yang dihasilkan juga tinggi, dianggap mudah dipahami, sangat mudah berkonsentrasi, menyenangkan, dan mendukung komunikasi antarsiswa di kelas. (2) Sebaliknya, pelajaran yang tidak atau kurang disukai akan menghasilkan nilai yang rendah, dianggap sulit dipahami, membosankan, sulit berkonsentrasi, terlalu lama atau membuang waktu, dan beberapa ekspresi negatif lainnya. (3) Media komunikasi yang digunakan siswa secara daring lebih terbatas dengan pelajaran yang lebih disukai, secara tidak langsung menunjukkan longgarnya ketergantungan terhadap media selain tatap muka. Hal ini diperkuat dengan metode diskusi atau tanya jawab dan menuliskan materi melalui papan tulis oleh guru Kimia. (4) Demikian pula, media yang berbau teknologi seperti penggunaan LCD dengan powerpoint ternyata belum tentu menjamin suasana kelas yang mendukung apalagi menjadikan pelajaran disukai oleh siswa, seperti mata pelajaran Bahasa Inggris dan Biologi.

\section{Saran}

Mengingat peran guru yang sangat penting dalam membentuk suasana belajar di dalam kelas, terutama dalam mengendalikan siswa dan jalannya pembelajaran, guru perlu dibekali keterampilan dalam berkomunikasi secara verbal yang efektif, tanpa harus bergantung pada teknologi kekinian, seperti layar LCD dengan powerpoint atau media komunikasi daring. Kedua, perlunya membuka kesadaran guru dalam menggunakan wewenangnya memanfaatkan secara kreatif benda-benda fisik, perabot, atau ruang kegiatan pembelajaran tanpa harus terikat pada tembok ruang kelas termasuk pengaturan waktu, posisi duduk, dan lain sebagainya sebagai sarana komunikasi non-verbal. Analisis lebih mendalam perlu dilakukan untuk lebih merinci faktor-faktor apa saja yang dapat secara signifikan dapat meningkatkan komunikasi antara guru dengan siswa, baik saat memberikan materi pelajaran, maupun saat memberikan dan menyelesaikan tugas di sekolah, sehingga hasilnya akan dapat diterapkan secara praktis dan langsung.

\section{DAFTAR PUSTAKA}

Altman, I. (1975). The Environment and Social Behavior. Monterey, CA: Brooks/Cole.

American Institute of Architects (AIA). (2002). Educational Facilities. Victoria, Australia: The Images Publishing Group. 


\section{Peningkatan Pembelajaran Student-Centered SMAK Santo Yusup Surabaya...}

Lya Dewi Anggraini, Natalia Christiani, Hebert Adrianto

Arimbawa, W., \& Santhyasa, I. K. G. (2010). Perspektif: Ruang sebagai entitas budaya lokal orientasi simbolik ruang masyarakat tradisional Desa Adat Penglipuran, Bangli-Bali. Local Wisdom: Jurnal IImiah Online, 2(4), 1-9

Boys, J. (2011). Towards Creative Learning Spaces: Re-Thinking the Architecture of Post-Compulsory Education. London dan New York: Routledge.

Feige, A., Wallbaum, H., Janser, M., \& Windlinger, L. (2013). Impact of sustainable office buildings on occupant's comfort and productivity. Journal of Corporate Real Estate, 15(1), 7-3. https://doi.org/10.1108/jcre-01-2013-0004

Ford, A. (2007). Designing the Sustainable School. Australia: The Images Publishing Group Pty Ltd.

Habraken. N. J. (2000). The Structure of the Ordinary: Form and Control in the Built Environment. USA: Graphic Composition.

Hameed, A., \& Amjad, S. (2009). Impact of office design on employees' productivity: A case study of banking organizations of Abbottabad, Pakistan. Journal of Public Affairs, Administration, and Management, 3(1) 1-13.

Haynes, B. (2008). The impact of office comfort on productivity. Journal of Facilities Management, 6(1), 37-51. https://doi.org/10.1108/14725960810847459

Idham, N. C. (2016). Arsitektur dan Kenyamanan Termal. Yogyakarta: Andi Offset

Laurens, J. M. (2004). Arsitektur dan Perilaku Manusia. Jakarta: PT Grasindo.

Ngalimun. (2017). Strategi Pembelajaran: Dilengkapi dengan 65 model pembelajaran. Yogyakarta: Parama IImu.

Rapoport, A. (2005). Culture, Architecture, and Design. Chicago, Illinois: Locke Science Publishing Company, Inc.

Yudhistiro, K., Sumartono, Prasetya, D. A., Nurdewanto, B., \& Sonalitha, E. (2019). Network education Sekolah Dasar Islam Mohammad Hatta Kota Malang. Jurnal Akses Pengabdian Indonesia, 4(2), 92-97.

Yunus, E. N., \& Ernawati, E. (2018). Productivity paradox? The impact of office redesign on employee productivity. International Journal of Productivity and Performance Management, 67(9), 19181939 https://doi.org/10.1108/ijppm-12-2017-0350

Yusup, I. R. (2016). Kesulitan guru pada pembelajaran Biologi tingkat Madrasah/ Sekolah di Provinsi Jawa Barat (Studi kasus wilayah Priangan Timur). Jurnal Program Studi Pendidikan Biologi, 8(2), 34-42. https://doi.org/10.15575/bioeduin.v8i2.3187 